\title{
Diversitas Serangga Penyerbuk dan Pembentukkan Buah Tanaman Kakao (Theobroma cacao L.)
}

\author{
Diversity of Pollinator Insects and Fruit Set of Cacao \\ (Theobroma cacao L.)
}

\author{
ARI NUGROHO', TRI ATMOWIDI ${ }^{1 *}$, SIH KAHONO ${ }^{2}$ \\ 'Departemen Biologi, Fakultas Matematika dan Ilmu Pengetahuan Alam, Institut Pertanian Bogor, \\ Kampus IPB Dramaga, Bogor 16680 \\ ${ }^{2}$ Laboratorium Entomologi, Divisi Zoologi, Pusat Penelitian Biologi-LIPI Cibinong, Bogor 16912
}

Diterima 8 Februari 2019/Disetujui 29 Mei 2019

\begin{abstract}
Cocoa (Theobroma cacao L.) is an entomophilous plant which is need insects for pollination. Pollinator insects increase cocoa's fruit set. The aim of this research were to study diversity of pollinator insects, visiting activity of fly, Forcipomyia (Diptera), and fruit set of cocoa. Observation of pollinator insects was conducted by scan sampling method. Visiting activity of Forcipomyia were observed based on duration visit per flower, number of flowers visited per minute, and duration of activity on flowers. Pollen load on body of Forcipomyia were measured. Pollination effectiveness of insect were measured from the number and size of the cocoa fruit. Result showed that 19 species of insects visitors on cocoa flowers were observed. Nine species are pollinator of cocoa's plants i.e. Forcipomyia, Cecidomyia, Stilobezzia, Drosophila, Orimarga, Dolichoderus, Pheidole, Megachile, and Nomia. Cocoa pollination by insects produced $3 \%$ fruit higher than flowers without insect pollination. Pollination by insects produced size and weight of fruit, and number of seed per fruit were higher than pollination without insects.
\end{abstract}

Key words: Cocoa, pollination, Forcipomyia, fruit set

\section{PENDAHULUAN}

Indonesia merupakan produsen kakao terbesar di dunia setelah Nigeria dan Pantai Gading (Mulato 2005). Perkebunan kakao semakin berkembang di berbagai daerah di Indonesia, yang memicu semakin meningkatnya produksi kakao. Produktivitas kakao dipengaruhi oleh teknik kultur, varietas tanaman kakao, serta kondisi lingkungan seperti tanah, iklim, dan serangga. Serangga dapat mempengaruhi produktivitas kakao karena dapat berperan sebagai agen penyerbuk, kontrol biologis, hama, dan vektor penyakit (Putra et al. 2011).

Tanaman kakao memiliki bunga tipe kauliflori, yaitu pertumbuhan bunga dari berkas ketiak daun pada batang dan cabang. Bunga kakao merupakan bunga hermaprodit, memiliki dua kelamin (putik dan benang sari) dalam satu bunga. Bunga kakao disusun oleh lima kelopak, lima mahkota, lima bakal buah, sepuluh tangkai sari yang tersusun dalam dua lingkaran, dengan masing-masing lingkaran terdiri dari lima tangkai sari fertil, dan tangkai

*Penulis korespondensi:

E-mail: atmowidi@apps.ipb.ac.id sari yang steril (staminodia). Benangsari yang fertil melengkung sehingga anther berkembang di dalam kantung kelopak (Wood dan Lass 1985). Karakter serbuksari yang terlindungi oleh kantung kelopak serta memiliki anther yang bersifat lengket (Young 1986) menjadikan tanaman kakao bersifat entomophilous, yaitu membutuhkan serangga dalam penyerbukannya (Gnanaratnam 1954).

Tanaman kakao berasosiasi dan bersimbiosis dengan serangga. Entwistle (1972) melaporkan terdapat 1500 spesies serangga yang berasosiasi dengan tanaman kakao. Frekuensi kunjungan serangga pada tanaman kakao di Ghana didominasi oleh Ceratopogonidae yang terdiri dari Cecidomyiids spp. dan Forcipomyia spp. (Adjaloo dan Oduro 2013). Mulato (2005) melaporkan bahwa kehadiran serangga penyerbuk pada tanaman kakao dapat membantu penyerbukan silang yang akan meningkatkan hasil buah dan biji. Serbuksari kakao yang dibawa oleh serangga ke stigma meningkatkan persentase keberhasilan terbentuknya buah sebesar $74 \%$ (Falque 1996). Penyerbukan bunga kakao secara terbuka dapat menghasilkan 5\% pembentukkan buah dari 
keseluruhan bunga yang ada di pohon (Harland 1925; Entwistle 1972; Lachenaud 1991).

Rendahnya persentase pembentukkan buah dapat disebabkan karena sebagian spesies tanaman kakao bersifat self incompatible, adanya persaingan fisiologis dari tanaman itu sendiri dan adanya serangan hama dan cendawan (Merijn et al. 2006). Oleh sebab itu, pengetahuan keragaman serangga pengunjung beserta peranya terhadap kakao sangat penting untuk dilakukan. Penelitian ini bertujuan mempelajari keragaman serangga penyerbuk, aktivitas kunjungan lalat Forcipomyia dan pembentukan buah kakao (Theobroma cacao L.).

\section{BAHAN DAN METODE}

\section{Pengamatan Keragaman Serangga}

Pengunjung. Pengamatan serangga dilakukan pada lahan perkebunan kakao seluas $550 \mathrm{~m}^{2}$ di kabupaten Lebak, provinsi Banten pada ketinggian $217 \mathrm{mdpl}$. Pengamatan serangga dilakukan pada pagi (pukul 06.00-08.30), siang (10.00-12.00), dan sore hari (13.00-15.00) selama 15 hari. Pengamatan serangga penyerbuk hanya dilakukan pada saat cuaca cerah dengan metode scan sampling (Martin dan Bateson 1993). Serangga yang belum dapat diidentifikasi di lapangan ditangkap dengan sweep net dan dimasukan kedalam botol yang berisi ether sebagai pembius serangga. Selanjutnya, serangga dimasukkan ke dalam botol berisi alkohol $70 \%$ untuk keperluan identifikasi. Pada saat pengamatan serangga dilakukan pengukuran parameter lingkungan di bawah naungan tanaman kakao, yang meliputi suhu, kelembapan udara, intensitas cahaya, serta kecepatan angin.

Pengamatan Aktivitas Kunjungan Forcipomyia. Pengamatan aktivitas kunjungan hanya dilakukan pada lalat penyerbuk, Forcipomyia berdasarkan Dafni (1992). Pengamatan kunjungan Forcipomyia meliputi lama kunjungan per bunga, (lamanya serangga berkunjung pada bunga dari serangga hinggap di bunga sampai serangga meninggalkan bunga), aktivitas kunjungan per bunga, (lamanya serangga aktif menyerbuki di bunga), dan jumlah bunga yang dikunjungi per menit, (menghitung jumlah bunga yang di kunjungi dalam satu menit). Pengamatan kunjungan dan jumlah bunga yang dikunjungi dilakukan sebanyak 15 kali pengamatan, sedangkan aktivitas kunjungan dilakukan empat kali pengamatan.

Identifikasi Serangga Pengunjung. Serangga yang berukuran relatif kecil diawetkan secara basah dengan alkohol $70 \%$ atau ditempatkan di point card. Serangga yang besar langsung dipin bagian toraksnya. Selanjutnya, serangga dimasukkan dalam oven pada suhu $35^{\circ} \mathrm{C}$ selama 3 hari (Borror et al.
1996). Identifikasi serangga berdasarkan (Alexander dan Byers 1981; Goulet and Huber (1993); Borror et al. 1996; Shattuck 1999). Serangga pengunjung bunga diidentifikasi dan dikelompokkan berdasarkan perannya.

Pengukuran Polen pada Tubuh Forcipomyia. Pengukuran polen dilakukan dengan memasukkan setiap individu Forcipomyia ke dalam micro tube yang berisi alkohol $70 \%$ dan gliserol (4:1). Selanjutnya lalat tersebut dimasukkan ke dalam rotator selama 2448 jam. Kemudian disentrifugasi dengan kecepatan $787.49 \mathrm{rpm}$ selama 10 menit. Sebanyak $0.1 \mathrm{ml}$ endapan yang dihasilkan, dihitung jumlah polen dibawah mikroskop menggunakan hemasitometer pada empat kuadran. Jumlah polen yang terhitung dikonversi ke jumlah total polen dari 10 kali ulangan.

Pengukuran Efektivitas Penyerbukan. Efektivitas penyerbukan diukur dari buah yang terbentuk pada bunga yang dikurung dengan kain kasa dan bunga yang terbuka. Lima kelompok bunga yang terdiri dari 25 bunga yang masih kuncup dalam satu pohon dikurung dengan kain kasa. Perlakuan ini dilakukan pada 11 pohon, sehingga total kelompok bunga yang dikurung adalah 55 kelompok. Pengurungan bunga bertujuan agar serangga tidak dapat menyerbuk bunga. Pengukuran buah dilakukan pada 7 minggu setelah perlakuan, yaitu pada bunga yang terbuka dan yang dikurung. Variabel yang dihitung meliputi jumlah buah yang terbentuk, ukuran buah (panjang dan diameter), bobot buah, dan jumlah biji per buah.

Analisis Data. Serangga pengunjung bunga kakao dihitung rata-rata dan persentase per periode waktu dan dihitung indeks keanekaragaman Shannon (H') dan kemerataan (E) (Magurran 1987). Kesamaan serangga pengunjung antar periode pengamatan (pagi, siang, dan sore) dihitung dengan indeks kesamaan Bray-Curtis (IBC). Indeks tersebut dapat menghitung kesamaan antara dua komunitas yang saling berbeda dengan menggunakan software Primer 5. Rumus yang di gunakan adalah:

$$
\begin{aligned}
& \mathrm{H}^{\prime}=-\sum \text { ni/N } \ln \text { ni/N } \\
& \mathrm{E}=\mathrm{H} / \ln \mathrm{S} \\
& \mathrm{I}_{\mathrm{BC}}=1-\left(\mathrm{i}^{\mathrm{n}}=1 \mathrm{Xi}-\mathrm{Yi} / \mathrm{i}^{\mathrm{n}}=1 \mathrm{Xi}+\mathrm{Yi}\right) \times 100 \% \\
& \text { Keterangan: } \\
& \mathrm{ni} \quad: \text { Jumlah individu jenis ke-i } \\
& \mathrm{N} \quad: \text { Total jumlah individu } \\
& \mathrm{ln} \quad: \text { Logaritma natural } \\
& \mathrm{S} \quad: \text { Jumlah spesies } \\
& \mathrm{Xi}-\mathrm{Yi}: \text { Nilai kelimpahan spesies i pada periode } \\
& \mathrm{n} \quad \text { berbeda } \\
& \text { Jumlah individu }
\end{aligned}
$$


Nilai frekuensi kunjungan dihitung dari jumlah kunjungan serangga Forcipomyia pada bunga kakao. Jumlah individu serangga pengunjung dikorelasikan dengan keempat parameter lingkungan dengan menggunakan software SPSS versi 16.0. Buah yang terbentuk pada bunga yang dikunjungi dibandingkan dengan bunga yang tidak dikunjungi serangga.

\section{HASIL}

Spesies yang mendominasi kunjungan bunga kakao, yaitu Forcipomyia spp. (79.14\%). Sembilan spesies dari 19 spesies serangga pengunjung merupakan penyerbuk bunga kakao, yaitu Forcipomyia sp., Cecidomyia sp., Stilobezzia sp., Drosophila sp., Orimarga sp., Dolichoderus sp., Pheidole sp., Megachile sp., dan Nomia sp.. Sedangkan yang lain merupakan serangga predator, hama, parasitoid, dan serangga pengunjung. Jumlah individu dan spesies serangga pengunjung paling tinggi terjadi pada pagi hari $(\mathrm{N}=10.06$ dan $\mathrm{S}=13)$. Indeks keragaman Shannon serangga pada siang hari $\left(H^{\prime}=0.98\right)$ lebih tinggi dibandingkan pagi hari $\left(H^{\prime}=0.94\right)$ dan sore hari (0.78). Indeks kemerataan Shannon yang paling tinggi terjadi pada sore hari $(E=0.48)$ (Tabel 1). Indeks kesamaan Bray-Curtis paling tinggi terjadi pada pagi-siang hari $(66.58 \%)$, sedangkan nilai yang paling kecil terjadi pada siangsore hari $(47.13 \%)$ (Tabel 2).

Pengukuran yang dilakukan selama 15 hari dibawah naungan kebun kakao, didapatkan suhu berkisar $25.3-33.3^{\circ} \mathrm{C}$, kelembapan udara 60.3-94, 8\%, intensitas cahaya 328-1998 lux, kecepatan angin $0-1.6 \mathrm{~m} /$ detik. Suhu tertinggi terjadi pada siang hari $\left(33.3^{\circ} \mathrm{C}\right)$, dengan kelembapan dan intensitas yang tinggi, yaitu 93.8\% dan 1998 lux. Kecepatan angin yang paling tinggi terdapat pada sore hari $(1.6 \mathrm{~m} /$ detik) (Tabel 3). Kelembapan udara berkorelasi positif dengan jumlah individu serangga pengunjung $\left(\mathrm{r}=0.517\right.$ dan $\left.\mathrm{R}^{2}=0.267\right)$. Suhu, intensitas cahaya, dan kecepatan angin berkorelasi negatif dangan jumlah individu serangga pengunjung $\left(\mathrm{r}=-0.531, \mathrm{R}^{2}=0.282\right.$; $\left.\mathrm{r}=-0.302, \mathrm{R}^{2}=0.125 ; \mathrm{r}=-0.520, \mathrm{R}^{2}=0.091\right)($ Tabel 4$)$.

Lama kunjungan Forcipomyia pada bunga kakao di pagi dan siang hari lebih rendah dibandingkan sore hari. Hal ini ditunjukan dari lama aktivitas kunjungan per bunga di pagi yang lebih tinggi (1.5 menit) dibandingkan siang dan sore hari (1.4 menit dan 1.2 menit). Aktivitas yang tinggi menyebabkan Forcipomyia lebih banyak mengunjungi bunga di pagi (1.07 bunga/menit) dibanding siang dan sore hari (1 bunga/menit) (Tabel 5). Lalat Forcipomyia rata-rata membawa sekitar 200 polen.

Peran Serangga dalam Pembentukan Buah Kakao. Pembentukan buah (fruit set) pada bunga kakao yang terbuka memberikan hasil yang lebih tinggi dibandingkan dengan bunga yang dikurung. Persentase keberhasilan fruit set yang dihasilkan dari bunga terbuka sebesar 4\% dengan jumlah buah yang terbentuk selama 7 minggu sebanyak 10 buah. Persentase keberhasilan fruit set yang dihasilkan dari bunga dikurung sebesar 1\% dengan jumlah buah yang terbentuk selama 7 minggu sebanyak 2 buah (Tabel 6). Hal ini menunjukan bahwa serangga membantu meningkatkan pembentukan buah. Ukuran buah yang terbentuk dari bunga yang terbuka baik panjang, diameter, bobot buah dan jumlah biji lebih besar dari buah yang terbentuk dari bunga yang dikurung (Tabel 7.

Tabel 1. Keragaman serangga pengunjung bunga kakao

\begin{tabular}{|c|c|c|c|c|c|}
\hline \multirow{2}{*}{$\begin{array}{l}\text { Ordo } \\
\text { Sub ordo } \\
\text { Spesies }\end{array}$} & \multicolumn{3}{|c|}{ Jumlah individu } & \multirow{2}{*}{ Total individu } & \multirow{2}{*}{ Persentase $(\%)$} \\
\hline & Pagi & Siang & Sore & & \\
\hline \multicolumn{6}{|l|}{ Diptera } \\
\hline \multicolumn{6}{|l|}{ Nematocera } \\
\hline Forcipomyia spp. & 8.19 & 4.73 & 1.99 & 14.19 & 79.14 \\
\hline Cecidomyia spp. & 0.46 & 0.06 & - & 0.52 & 2.76 \\
\hline Stilobezzia spp. & 0.26 & 0.2 & - & 0.46 & 2.44 \\
\hline Bradysia spp. & 0.13 & - & - & 0.13 & 0.69 \\
\hline Rondariella spp. & - & 0.06 & 0.06 & 0.12 & 0.64 \\
\hline \multicolumn{6}{|l|}{ Brachycera } \\
\hline Brachysera spp. & 0.13 & - & - & 0.13 & 0.69 \\
\hline Hermatia spp. & - & 0.13 & - & 0.13 & 0.69 \\
\hline \multicolumn{6}{|l|}{ Hymenoptera } \\
\hline \multicolumn{6}{|l|}{ Apocrita } \\
\hline Nomia sp. & 0.06 & 0.13 & - & 0.19 & 1.01 \\
\hline Megachile sp. & - & 0.06 & - & 0.06 & 0.32 \\
\hline Dolichoderus sp & 0.2 & 0.13 & - & 0.33 & 1.75 \\
\hline Pheidole sp. & 0.32 & 0.46 & - & 0.78 & 4.14 \\
\hline Apanteles sp. & 0.06 & - & - & 0.06 & 0.32 \\
\hline Brachymeria sp. & 0.13 & - & - & 0.13 & 0.69 \\
\hline Xanthocyptus sp. & - & 0.06 & - & 0.06 & 0.32 \\
\hline Xantophimpla sp. & - & 0.06 & - & 0.06 & 0.32 \\
\hline
\end{tabular}


Tabel 1. Lanjutan

\begin{tabular}{|c|c|c|c|c|c|}
\hline \multirow{3}{*}{$\begin{array}{l}\text { Ordo } \\
\text { Sub ordo } \\
\text { Spesies } \\
\end{array}$} & \multirow{2}{*}{\multicolumn{3}{|c|}{ Jumlah individu }} & \multirow{3}{*}{ Total individu } & \multirow{3}{*}{ Persentase $(\%)$} \\
\hline & & & & & \\
\hline & Pagi & Siang & Sore & & \\
\hline \multicolumn{6}{|l|}{ Lepidoptera } \\
\hline \multicolumn{6}{|l|}{ Heterocera } \\
\hline Delias sp. & - & - & 0.13 & 0.13 & 0.69 \\
\hline \multicolumn{6}{|l|}{ Coleoptera } \\
\hline \multicolumn{6}{|l|}{ Polyphaga } \\
\hline Apogonia sp. & 0.06 & - & - & 0.06 & 0.32 \\
\hline Jumlah individu (N) & 10.06 & 6.14 & 2.51 & 18.71 & 100 \\
\hline Jumlah spesies (S) & 13 & 12 & 6 & 19 & \\
\hline Indeks keragaman shannon (H') & 0.94 & 0.98 & 0.78 & 1.06 & \\
\hline Indeks kemerataan shannon (E) & 0.36 & 0.39 & 0.48 & 0.35 & \\
\hline
\end{tabular}

Tabel 2. Kesamaan serangga pengunjung bunga kakao berdasarkan indeks kesamaan Bray-Curtis

\begin{tabular}{lccc}
\hline Waktu & $\begin{array}{c}\text { Pagi } \\
(06.00-08.30)\end{array}$ & $\begin{array}{c}\text { Siang } \\
(10.00-12.00)\end{array}$ & $\begin{array}{c}\text { Sore } \\
(13.00-15.00)\end{array}$ \\
\hline $\begin{array}{l}\text { Pagi } \\
(06.00-08.30)\end{array}$ & - & - & - \\
$\begin{array}{l}\text { Siang } \\
(10.00-12.00)\end{array}$ & 66.58 & - & - \\
$\begin{array}{l}\text { Sore } \\
(13.00-15.00)\end{array}$ & 53.68 & 47.13 & - \\
\hline
\end{tabular}

Tabel 3. Data parameter lingkungan di lokasi pengamatan pada periode waktu pagi, siang, dan sore hari

\begin{tabular}{llll}
\hline $\begin{array}{l}\text { Parameter } \\
\text { lingkungan }\end{array}$ & \multicolumn{1}{c}{ Pagi } & \multicolumn{1}{c}{ Siang } & \multicolumn{1}{c}{ Sore } \\
\hline Suhu udara $\left({ }^{\circ} \mathrm{C}\right)$ & 26.7 & 30.1 & 30.2 \\
& $(25.3-28.2)$ & $(27.6-33.3)$ & $(28.2-33.2)$ \\
Kelembapan & 81.3 & 74.5 & 73.5 \\
udara $(\%)$ & $(74.3-94.0)$ & $(60.3-93.8)$ & $(63.9-83.7)$ \\
Intensitas cahaya & 869 & 1497.9 & 1340.9 \\
$($ lux $)$ & $(328-1833)$ & $(448-1998)$ & $(525-1903)$ \\
Kecepatan angin & 0.1 & 0.5 & 0.3 \\
$(\mathrm{~m} /$ detik) & $(0-1.3)$ & $(0-1.2)$ & $(0.3-1.6)$ \\
\hline
\end{tabular}

Tabel 4. Korelasi Pearson antara jumlah individu serangga pengunjung dengan parameter lingkungan

\begin{tabular}{lrc}
\hline Kualitas Lingkungan & $\mathrm{r}$ & $\mathrm{R}^{2}$ \\
\hline Suhu udara $\left({ }^{\circ} \mathrm{C}\right)$ & -0.531 & 0.282 \\
Kelembapan udara (\%) & 0.517 & 0.267 \\
Intensitas cahaya (lux) & -0.302 & 0.125 \\
Kecepatan angin (m/detik) & -0.520 & 0.270 \\
\hline
\end{tabular}

Tabel 5. Lama kunjungan, aktivitas kunjungan Forcipomyia sp., dan banyak bunga dikunjungi per menit pada tiga periode waktu

\begin{tabular}{lcccc}
\hline $\begin{array}{l}\text { Pengamatan } \\
\text { Kunjungan }\end{array}$ & Pagi & Siang & Sore & Rata-rata \\
\hline $\begin{array}{l}\text { Lama kunjungan } \\
\text { perbunga (menit) }\end{array}$ & 6.4 & 6.2 & 7.5 & 6.7 \\
$\begin{array}{l}\text { Aktivitas } \\
\text { kunjungan dalam } \\
\text { satu bunga } \\
\text { (menit) }\end{array}$ & 1.5 & 1.4 & 1.2 & 1.4 \\
$\begin{array}{l}\text { Jumlah bunga } \\
\text { di kunjungi per } \\
\text { menit (bunga) }\end{array}$ & 1.07 & 1.0 & 1.0 & 1.02 \\
\hline
\end{tabular}

\section{PEMBAHASAN}

Keragaman Serangga Pengunjung Kakao. Serangga pegunjung dapat dikelompokan sebagai penyerbuk, predator, hama, dan parasitoid. Serangga pengunjung dikatakan sebagai penyerbuk apabila memiliki kecocokan, ukuran atau morfologi, waktu kesiapan bunga terhadap kunjungan serangga, frekuensi kunjungan, dan sifat dari bunga (Kahono; komunikasi pribadi). Berdasarkan pertimbangan kecocokan tersebut, maka serangga pengunjung yang merupakan penyerbuk bunga kakao ialah Forcipomyia spp., Cecidomyia spp., Stilobezzia sp., Drosophila spp., Orimarga sp. (Diptera), Dolichoderus sp., Pheidole sp., Megachile sp., dan Nomia sp. (Hymenoptera). Serangga yang dominan menyerbuki bunga kakao termasuk dalam ordo Diptera dan Hymenoptera.

Di Ghana dilaporkan serangga pengunjung yang berperan sebagai agen penyerbuk bunga kakao ialah Cecidomyiid spp., Forcipomyia spp., Drosophila spp., Hypotrigona aurajoi, Camponotus acvapimensis, Cremastogaster depresa, Cremastogaster africana, Cremastogaster clariventris, Pheidole megacephala (Adjalo dan Oduro 2013). Glendinning (1972) menyimpulkan bahwa Forcipomyia spp. merupakan penyerbuk utama pada tanaman kakao di Afrika Barat. Kaufman (1975) dan Young (1986) menyatakan bahwa lebah dapat menjadi agen penyerbuk bagi bunga kakao dengan efektivitas penyerbukan yang rendah. Jenis-jenis lebah yang dapat membawa polen dari bunga kakao termasuk dalam famili Apidae, Megachilidae, dan Halictidae (Kaufman 1975).

Serangga predator atau pemangsa adalah serangga yang memakan serangga lain. Serangga ini memberikan kontribusi penting dalam ekosistem perkebunan kakao sebagai pengendali hayati yang dapat menekan hama kakao. Dari hasil pengamatan, Teganaria sp. (laba-laba) dan Dolichoderus sp. (semut 
Tabel 6. Rata-rata fruit set dari bunga kakao yang terbuka dan bunga yang dikurung dengan kain kasa

\begin{tabular}{|c|c|c|c|c|c|c|c|}
\hline \multicolumn{4}{|c|}{ Bunga terbuka } & \multicolumn{4}{|c|}{ Bunga dikurung } \\
\hline Pohon & $\sum$ bunga & $\sum$ buah setelah 7 minggu & Fruit set $(\%)$ & Pohon & $\sum$ bunga & $\sum$ buah setelah 7 minggu & Fruit set $(\%)$ \\
\hline 1 & 25 & 2 & 8 & 1 & 25 & 0 & 0 \\
\hline 2 & 25 & 1 & 4 & 2 & 25 & 0 & 0 \\
\hline 3 & 25 & 1 & 4 & 3 & 25 & 1 & 4 \\
\hline 4 & 25 & 1 & 4 & 4 & 25 & 0 & 0 \\
\hline 5 & 25 & 1 & 4 & 5 & 25 & 0 & 0 \\
\hline 6 & 25 & 2 & 8 & 6 & 25 & 0 & 0 \\
\hline 7 & 25 & 0 & 0 & 7 & 25 & 1 & 4 \\
\hline 8 & 25 & 2 & 8 & 8 & 25 & 0 & 0 \\
\hline 9 & 25 & 0 & 0 & 9 & 25 & 0 & 0 \\
\hline 10 & 25 & 0 & 0 & 10 & 25 & 0 & 0 \\
\hline 11 & 25 & 0 & 0 & 11 & 25 & 0 & 0 \\
\hline Jumlah & 275 & 10 & 40 & Jumlah & 275 & 2 & 8 \\
\hline Rata-rat & & & 4 & Rata-rata & & & 1 \\
\hline
\end{tabular}

Tabel 7. Perbandingan buah kakao hasil panen umur 7 minggu dari bunga terbuka dan bunga dikurung dengan kain kasa

\begin{tabular}{lcc}
\hline Ukuran buah & \multicolumn{1}{c}{ Terbuka } & \multicolumn{1}{c}{ Dikurung } \\
\hline Panjang $(\mathrm{cm})$ & $6.04(5.01-6.92)$ & $3.85(3.61-4.1)$ \\
Diameter $(\mathrm{cm})$ & $2.45(1.83-3.04)$ & $1.55(1.50-1.60)$ \\
Bobot buah $(\mathrm{g})$ & $17.18(6.20-31.60)$ & $4.2(3.4-5)$ \\
Jumlah biji & $41.36(32-54)$ & $39.5(38-41)$ \\
\hline
\end{tabular}

Angka dalam kurung menunjukan ukuran minimum dan maksimum

hitam) merupakan predator yang berkunjung di bunga kakao. Tegenaria sp. merupakan Arthopoda yang mengunjungi bunga kakao pada saat pengamatan. Semut dan laba-laba merupakan predator yang efektif dalam menekan populasi hama yang menyerang kakao, seperti Helopeltis sp. yang mengisap buah kakao sehingga buah menjadi busuk dan ngengat sebagai hama penggerek batang dan cabang (Hindayana et al. 2002).

Serangga hama tanaman kakao, yaitu Apogonia sp. (kumbang) merupakan hama pemakan daun dan bunga yang masih muda. Kumbang ini menyerang tanaman pada malam hari. Serangga ini memiliki musuh alami, yaitu semut (Hindayana et al. 2002).

Serangga lain yang berkunjung pada bunga kakao adalah serangga parasitoid, yaitu Brachymeria sp., Apanteles sp., Xanthocryptus sp., Xantophimpla sp., dan Rondariella sp. Tawon parasitoid dengan persentase sebesar $66.7 \%$ dari total Hymenoptera yang didapatkan pada pengamatan. Sahari (2004), melaporkan sebanyak 27.8\% dari Hymenoptera di agroforestri di Sulawesi Tengah merupakan tawon parasitoid, yang terdiri dari 7 famili, yaitu Braconidae, Scelionidae, Enccrytidae, Ichneumonidae, Platygastridae, dan Ceraphronidae. Rondariella sp. merupakan parasitoid yang dapat membantu menekan hama di China, Eropa, dan Jawa (Indonesia) (Yu et al. 2004). Parasitoid merupakan serangga yang penting dalam ekosistem perkebunan kakao. Umumnya serangga parasitoid didominasi oleh Hymenoptera dan Diptera. Hymenoptera yang bersifat parasitoid dapat mengatur populasi dari serangga herbivora dan mengontrol hama pada kakao (Noyes dan Hayat 1984). Lebah parasitoid menyerang inangnya dengan cara memasukan telur ke dalam telur inangnya, seperti telur ulat, kutu, dan kepik. Parasitoid ini dapat meletakan telurnya langsung pada tubuh inangnya, baik yang masih hidup atau yang sudah mati, dan larva parasitoid dapat memakan tubuh inangnya. Lalat parasitoid meletakan telurnya di daun, kemudian telur tersebut dapat masuk dan tumbuh di dalam tubuh larva (Hindayana et al. 2002).

Serangga lain yang berkunjung pada bunga kakao ialah Delias sp. (kupu-kupu), Bradysia sp., Brachycera sp., dan Hermatia sp. (lalat). Adjaloo dan Oduro (2013) melaporkan bahwa sebanyak 2.9\% serangga yang terdapat di perkebunan kakao di Ghana adalah Lepidoptera. Ordo tersebut tidak melakukan penyerbukan pada bunga kakao, karena ukuran bunga kakao yang kecil dan tidak memiliki nektar. Beberapa spesies ordo Lepidoptera merupakan hama penggerek buah kakao, yaitu Conopomorpha cramerella (Hindayana et al. 2002). Bradysia sp. dan Brachycera sp. merupakan serangga yang hidup di tempat yang lembab (Lenanders 2000) dan menghisap cairan jamur (Tepper dan Bradley 1989). Hermatia sp. yang dikenal sebagai black soldier fly diamati hinggap di bunga kakao singkat. Menurut Khairiah (2012), H. illucens dilaporkan sebagai serangga pengunjung pada bunga pacar (Impatiens balsamina).

Kunjungan serangga yang tertinggi terjadi pada pagi hari. Hal ini berkaitan dengan waktu antesis bunga kakao yang terjadi pada pukul 05.3006.30 (Lachenaud 1991). Semakin banyak bunga yang antesis, maka semakin banyak serangga yang berkunjung. Kelimpahan bunga dapat mempengaruhi keragaman dan jumlah serangga pengunjung (Atmowidi et al. 2007). Penyerbukan kakao terjadi pada pukul 07.30-10.30 pada kondisi lembab dan sedikit cahaya (Falque 1996). Rianti (2009) melaporkan bahwa frekuensi penyerbukan tertinggi pada bunga jarak pagar pada pukul 07.0009.15. Keragaman serangga tertinggi tinggi pada pukul 10.00-12.00 $\left(\mathrm{H}^{\prime}=0.98\right)$ dan terendah pada 
pukul 14.00-16.00 $\left(\mathrm{H}^{\prime}=0.48\right)$. Jumlah individu Forcipomyia spp. mendominasi frekuensi pada ketiga periode pengamatan. Berdasarkan laporan Hernandez (1965), Forcipomyia spp. di Costa Rica membantu penyebaran polen ke stigma kakao dengan persentase keberhasilan sebesar 53-76\%. Di Ghana, frekuensi kunjungan tertinggi pada kakao dilakukan oleh Cecidomyiid dengan persentase $65 \%$, disusul oleh Forcipomyia sebesar 52\% (Adjaloo dan Oduro 2013). Berdasarkan indeks kesamaan Bray-Curtis, kesamaan serangga di pagi-siang hari merupakan nilai yang tertinggi. Hal tersebut disebabkan adanya jumlah individu serangga yang mendominasi setiap periode pengamatan, yaitu Forcipomyia spp.. Keaktifan Ceratopogonidae (Forcipomyia) dalam penyerbukan bunga kakao dimulai pukul 06.00 sampai pukul 19.00 (Frimpong et al. 2009).

Hasil analisis antara jumlah individu serangga pengunjung dengan parameter lingkungan menunjukan bahwa kelembapan udara berkorelasi positif dengan jumlah individu serangga pengunjung. Kelembapan udara yang optimum untuk kunjungan serangga pada kisaran 63-85\%. Penyerbukan bunga kakao yang dilakukan oleh serangga, khususnya Ceratopogonidae (Forcipomyia spp. dan Cecidomyia spp.) terjadi pada saat intensitas cahaya yang rendah dan lembab (Falque 1996). Suhu, intensitas cahaya, dan kecepatan angin berkorelasi negatif dengan jumlah individu serangga pengunjung. Kelimpahan serangga tertinggi terjadi pada kisaran suhu, intensitas cahaya, dan kecepatan angin yang optimum, yaitu $25-31^{\circ} \mathrm{C}, 400-1999$ lux, dan 0-0.5 m/detik. Hasil penelitian ini sesuai yang dilaporkan Rianti (2009) pada bunga jarak pagar, yaitu kelembapan udara berkorelasi positif dengan jumlah individu serangga pengunjung, sedangkan suhu, intensitas cahaya, dan kecepatan angin berkorelasi negatif.

Aktivitas Kunjungan Forcipomyia dan Pollen Load. Lama kunjungan Forcipomyia yang paling singkat terjadi pada pagi hari. Hal ini menunjukan bahwa Forcipomyia lebih aktif berpindah bunga. Lama kunjungan paling lama terjadi pada sore hari. Pada sore hari, Forcipomyia lebih pasif dan lebih memilih menetap pada satu bunga. Aktivitas kunjungan Forcipomyia yang terlama adalah pada pagi hari, sedangkan yang terpendek pada sore hari. Forcipomyia merupakan agen penyerbuk utama bunga kakao (Glendinning 1958; Hernandez 1965; Sulistyowati 1986; Falque 1996).

Berdasarkan hasil pengamatan, jumlah bunga yang dikunjungi selama satu menit, pada pagi hari menunjukan angka tertinggi. Pada pagi hari Forcipomyia dapat mengunjungi lebih dari satu bunga dalam satu menit. Di siang dan sore hari, lalat ini hanya mengunjungi satu bunga setiap menitnya.
Hal ini sesuai dengan laporan Falque (1996) yang menyebutkan bahwa penyerbukan bunga kakao yang baik dibantu oleh serangga Forcipomyia yang berlangsung pada pagi hari yaitu pukul 07.30-10.30 WIB.

Rata-rata pollen load pada Forcipomyia sebesar 200 polen. Falque et al. (1995) melaporkan bahwa terdapat 238 serbuksari pada stigma untuk penyerbukan tanaman oleh Forcipomyia. Tubuh lalat ini memiliki banyak rambut halus pada toraks, abdomen, dan tungkai sehingga memungkinkan tubuh lalat ini membawa polen kakao yang lengket (Young 1986).

Peran Serangga dalam Pembentukan Buah Kakao. Terdapat perbedaan keberhasilan terbentuknya buah dari bunga yang terbuka dengan bunga yang dikurung. Bunga yang terbuka memberikan peluang kepada serangga untuk membantu penyerbukan. Sedangkan bunga yang dikurung tidak mendapatkan bantuan serangga dalam penyerbukan. Berdasarkan penelitian ini, serangga dapat meningkatkan fruit set tanaman kakao sebesar 3\%. Harland (1925), Entwistle (1972), Lachenaud (1991) menyatakan bahwa penyerbukan bunga kakao yang terbuka dapat menghasilkan 5\% fruit set. Perbedaan fruit set ini kemungkinan di pengaruhi oleh umur pohon yang diamati yaitu sekitar 5 tahun. Tanaman kakao mulai berbunga pada umur empat sampai sembilan tahun (Wood dan Lass 1985). Sedikitnya buah yang terbentuk pada tanaman kakao, dapat juga disebabkan karena terjadi serangan serangga hama, cendawan patogen dan pengaruh fisiologis dari tanaman (Merijn et al. 2006).

Penyerbukan oleh serangga pada bunga kakao yang terbuka menghasilkan ukuran, diameter, bobot buah, dan jumlah biji yang lebih besar dibandingkan dengan hasil panen dari bunga yang dikurung. Secara umum, biji yang terdapat pada buah kakao berkisar antara 40-50 biji. Semakin tinggi frekuensi penyerbukan oleh serangga, maka peluang terbentuknya biji akan semakin tinggi dan mempengaruhi ukuran buah kakao (Falque 1996).

\section{KESIMPULAN}

Komunitas serangga pengunjung bunga kakao yang terdapat di Kabupaten Lebak, Banten terdiri dari 19 spesies. Sembilan spesies diantaranya merupakan agen penyerbuk, yaitu Forcipomyia sp., Cecidomyia sp., Stilobezzia sp., Drosophila sp., Orimarga sp., Dolichoderus sp., Pheidole sp., Megachile sp., dan Nomia sp.. Lalat Forcipomyia spp. merupakan serangga penyerbuk utama pada tanaman kakao. Serangga pengunjung di pagi dan siang hari memiliki nilai kesamaan yang tinggi. Forcipomyia lebih aktif 
berkunjung di pagi hari dengan mengunjungi lebih banyak bunga. Rata-rata pollen load pada Forcipomyia sebesar 200 polen. Buah yang terbentuk pada bunga terbuka dengan bantuan serangga 3\% lebih tinggi dibandingkan dengan bunga yang dikurung. Buah hasil penyerbukan serangga mempunyai ukuran, bobot buah, dan jumlah biji lebih besar dibandingkan dengan buah yang dihasilkan dari bunga yang dikurung.

\section{UCAPAN TERIMA KASIH}

Terima kasih penulis ucapkan kepada Dr. Awit Suwito yang telah membantu identifikasi lalat, Dr. Woro A Noerdjito yang membantu identifikasi Hymenoptera dan bapak Sugiyanto sebagai teknisi di Laboratorium Entomologi, Bidang Zoologi, Pusat Penelitian Biologi LIPI.

\section{DAFTAR PUSTAKA}

Alexander CP, Byers GW. 1981. Manual of Nearctic Diptera Vol 1 and 2. Ottawa (CA): Agriculture Canada Monograph.

Atmowidi T, Buchori D, Manuworoto S, Suryobroto B, Hidayat P. 2007. Diversity of pollinator insects in relation to seed set of mustard (Brassica rapa L.: Cruciferae). HAYATI J Biosci 14:155-161.

Adjaloo MK, Oduro W. 2013. Insect assemblage and the pollination system in cocoa ecosystems. J Appl Biosci 62:4582-4594.

Borror DJ, Triplehorn CA, Johnson NF. 1996. Pengenalan Pelajaran Serangga Ed. ke-6. Yogyakarta: UGM Press.

Dafni A. 1992. Pollination Ecology: A Pratical Approach. Oxford: Univ Press.

Entwistle PF. 1972. Pests of Cocoa First Edition. London: Longman Press.

Falque M, Vaissière BE, Vincent A, Eskes A. 1995. Effect of pollination intensity on fruit and seed set in cacao (Theobroma cacao L.). Sex Plant Reprod 8:354-360.

Falque M, Lesdalns C, Eskes A. 1996. Comparison of two cacao (Theobroma cacao L.) clones for the effect of pollination intensity on fruit set and seed content. Sex Plant Reprod 9:221-227.

Frimpong EA, Gordon I, Kwapong PK, Herren BG. 2009. Dynamics of cocoa pollination: tools and applications for surveying and monitoring cocoa pollinators. Int $J$ of Trop Ins Sci 29:62-69.

Glendinning DR. 1972. Natural pollination of cocoa. New Phytologist 71:719-729.

Gnanaratnam JK. 1954. Pollination mechanism of the cacao flower. Trop Agr 110:98-104.

Goulet H, Huber JT. 1993. Hymenoptera of The World: An Identification Guide to Families. Ottawa: Agriculture Canada.

Harland SC. 1925. Studies in cacao part 1 (the method of pollination). Ann Appl Biol 12:403-409.
Hernandez BJ. 1965. Insect pollination of cacao (Theobroma cacao L.) in Costa Rica [Disertasi]. Madison: University of Wisconsin.

Hindayana D et al. 2002. Musuh Alami, Hama dan Penyakit Tanaman Kakao. Jakarta: Departemen Pertanian.

Kaufman T. 1975. Ecology and behaviour of cocoa pollinating ceratopogonidae in Ghana, W. Africa. Envir Entomol 4:347-351.

Khairiah N, Dahelmi, Syamsuardi. 2012. Jenis-jenis serangga pengunjung bunga pacar air (Impatiens balsamina Linn.:Balsaminaceae). J Bio UA 1:9-14.

Lachenaud P. 1991. Facteurs de la fructification chez le cacaoyer (Theobroma cacao L.). Influence sur le nombre de graines parfruit [Disertasi]. Grignon: Institut National Agronomique.

Lenanders. 2000. Lakes and Watercourses. Stockholm: Aralia.

Magurran AE. 1987. Ecological Diversity and Its Measurement. New Jersey: Princeton University Press.

Martin P, Bateson P. 1986. Measuring Behavior: an Introductory Guide. Cambridge: Cambridge University Press.

Merijn MB, Dewenter IS, Tscharntke T. 2006. Shade tree management affects fruit abortion, insect pests adn pathogens of cacao. Agriculture, Ecosystems and Environment 120:201-205.

Mulato S et al. 2005. Pengolahan Produk Primer dan Sekunder Kakao. Jember: PT. Agromedia Pustaka.

Noyes JS, Hayat M. 1984. A review of the genera of Indo-Pacific Encyrtidae (Hymenoptera: Chalcidoidea). Bull Br Mus nat Hist (Ent) 48:131-395.

Putra IGAP, Watiniasih NL, Suartini NM. 2011. Inventarisasi serangga pada perkebunan kakao (Theobroma cacao) laboratorium unit perlindungan tanaman Desa Bedulu, Kecamatan Blahbatuh, Kabupaten Gianyar, Bali. Jurnal Biologi 14:19-24.

Rianti P. 2009. Keragaman, efektivitas, dan perilaku kunjungan serangga penyerbuk pada tanaman jarak pagar (Jatropha curcas L. Euphorbiaceae) [Tesis]. Bogor: Institut Pertanian Bogor.

Sahari B. 2004. Pengaruh isolasi terhadap dinamika struktur komunitas serangga dan keanekaragaman Hymenoptera parasitika dalam konteks waktu pada sistem agroforestri perkebunan kakao di tepi Taman Nasional Lore Lindu, Sulawesi Tengah [Tesis]. Bogor: Institut Pertanian Bogor.

Shattuck SO. 1999. Australian Ants: Their Biology and Identification. Monographs on Invertebrate Taxonomy Vol 3. Collingwood: Csiro publishing.

Sulistyowati E. 1986. Orientasi pengaruh keramaian lalu lintas terhadap jumlah buah cokelat per pohon. ISSN 54:41-44.

Tepper B, Bradley BP. 1989. Temporal changes in a natural population of copepods. Biol Bull 176:32-40.

Wood GAR, Lass RA. 1985. Cocoa fourth edition. London: Longman.

Young AM. 1986. Cocoa pollination. Cocoa Growers'Bulletin 37:5-23.

Yu Xiao-xia, Wu Hong, Chen Xue-xin, Shi Min, Wu qiong. 2004. Two new species of the genus Rondaniella Johannsen (Diptera: Mycetophilidae) from China. Entomotaxonomia 26:288-292. 